\title{
Expression of P2X and P2Y receptors in the intramural parasympathetic ganglia of the cat urinary bladder
}

Huai Zhen Ruan ${ }^{\mathrm{a}, \mathrm{b}}$, Lori A. Birder ${ }^{\mathrm{c}, \mathrm{d}}$, Zhenghua Xiang ${ }^{\mathrm{a}, \mathrm{f}}$, Bikramjit Chopra ${ }^{\mathrm{c}}$, Tony Buffington $^{\mathrm{e}}$, Changfeng Tai ${ }^{\mathrm{d}}$, James R. Roppolo ${ }^{\mathrm{d}}$, William C. de Groat ${ }^{\mathrm{d}}$ and Geoffrey Burnstock $^{\mathrm{a}}$

Running title: P2 receptor expression of cat bladder intramural ganglia

${ }^{a}$ Autonomic Neuroscience Centre, Royal Free and University College Medical School, Rowland Hill Street, London NW3 2PF

${ }^{\mathrm{b}}$ Department of Neurobiology, Third Military Medical University, Chongqing 400038, P

R China

University of Pittsburgh School of Medicine, Departments of ${ }^{\mathrm{c}}$ Medicine and

${ }^{\mathrm{d}}$ Pharmacology, Pittsburgh, PA 15261

${ }^{\mathrm{e}}$ Ohio State University Department of Clinical Veterinary Sciences, Columbus Ohio 43210

${ }^{\mathrm{f}}$ Department of Biochemistry and Molecular Biology, Second Military Medical University 200433 Shanghai, P R China

Corresponding Author: Professor Geoffrey Burnstock, Autonomic Neuroscience Centre Royal Free and University College Medical School, Rowland Hill Street, London NW3 2PF, UK.

Tel: +44 (0) 2078302948

Fax: +44 (0) 2078302949

E-mail: g.burnstock@ucl.ac.uk 


\begin{abstract}
The distribution and function of $\mathrm{P} 2 \mathrm{X}$ and $\mathrm{P} 2 \mathrm{Y}$ receptor subtypes was investigated on intact or cultured intramural ganglia of the cat urinary bladder by immunocytochemistry and calcium imaging techniques respectively. Neurons were labeled by all seven P2X receptor subtype antibodies and antibodies for $\mathrm{P} 2 \mathrm{Y}_{2}, \mathrm{P}_{2} \mathrm{Y}_{4}, \mathrm{P} 2 \mathrm{Y}_{6}$ and $\mathrm{P} 2 \mathrm{Y}_{12}$ receptor subtypes with a staining intensity of immunoreactivity in the following order:
\end{abstract} $\mathrm{P} 2 \mathrm{X}_{3}=\mathrm{P} 2 \mathrm{Y}_{2}=\mathrm{P} 2 \mathrm{Y}_{4}=\mathrm{P} 2 \mathrm{Y}_{6}=\mathrm{P} 2 \mathrm{Y}_{12}>\mathrm{P} 2 \mathrm{X}_{1}=\mathrm{P} 2 \mathrm{X}_{2}=\mathrm{P} 2 \mathrm{X}_{4}>\mathrm{P} 2 \mathrm{X}_{5}=\mathrm{P} 2 \mathrm{X}_{6}=\mathrm{P} 2 \mathrm{X}_{7} . \mathrm{P}_{2} \mathrm{Y}_{1}$ receptor antibodies labelled glial cells, but not neurons. $\mathrm{P}_{2} \mathrm{X}_{3}$ and $\mathrm{P}_{2} \mathrm{Y}_{4}$ polyclonal antibodies labelled about $95 \%$ and $40 \%$ of neurons, respectively. Double staining showed that $100 \%, 48.8 \%$ and $97.4 \%$ of $\mathrm{P}_{2} \mathrm{X}_{3}$ receptor-positive neurons coexpressed choline acetyl transferase (ChAT), nitric oxide synthase (NOS) and neurofilament 200 (NF200), respectively; while $100 \%, 59.2 \%$ and $97.6 \%$ of $\mathrm{P}_{2} \mathrm{Y}_{4}$ receptor-positive neurones coexpressed ChAT, NOS and NF200, respectively. Application of adenosine 5'triphospahte (ATP), $\alpha, \beta$-methylene ATP and uridine triphosphate elevated $\left[\mathrm{Ca}^{2+}\right]_{\mathrm{i}}$ in a subpopulation of dissociated cultured cat intramural ganglia neurons, demonstrating the presence of functional $\mathrm{P}_{2} \mathrm{Y}_{4}$ and $\mathrm{P} 2 \mathrm{X}_{3}$ receptors. This study indicates that $\mathrm{P} 2 \mathrm{X}$ and $\mathrm{P} 2 \mathrm{Y}$ receptor subtypes are expressed by cholinergic parasympathetic neurons innervating the urinary bladder. The neurons were also stained for NF200, usually regarded as a marker for large sensory neurons. These novel histochemical properties of cholinergic neurons in the cat bladder suggest that the parasympathetic pathways to the cat bladder may be modulated by complex purinergic synaptic mechanisms.

Keywords: P2X receptor; P2Y receptor; ATP; intramural ganglia; bladder; cat 


\section{Introduction}

Sympathetic as well as parasympathetic neurons and fibers are present in the pelvic ganglia or intramural ganglia of the bladder in different species $(4,17,26)$. In addition to the classical transmitters norepinephrine (NE) and acetylcholine (ACh), other substances, including vasoactive intestinal polypeptide (VIP), calcitonin gene-related peptide (CGRP), substance P (SP), enkephalin, somatostatin, neuropeptide Y, adenosine5 'triphosphate (ATP) and nitric oxide (NO) have been identified in intramural ganglia and nerves supplying the bladder and urethra $(17,37,38,46,47)$. These substances may act as neurotransmitters, neuromodulators, or trophic factors in the urinary bladder (17).

The role of ATP in the neural control of the bladder has attracted considerable attention because it has been identified as an excitatory cotransmitter released with ACh by parasympathetic postganglionic nerves (10) and may activate afferent nerves following release from urothelium $(14,22,42)$. Previous pharmacological studies also revealed that purinergic agents have both excitatory and inhibitory effects on transmission in parasympathetic ganglia in the pelvic plexus and in the wall of the cat urinary bladder $(3,18,21,40)$. In vivo experiments revealed that low doses of ATP, adenosine diphosphate (ADP), adenosine monophosphate (AMP) and adenosine inhibited cholinergic ganglionic transmission, whereas high doses of ATP directly excited the ganglion cells. The inhibitory effects of purinergic agents were antagonized by theophylline and therefore are likely to be mediated by P1 purinergic receptors. Inhibitory effects of exogenous and endogenously released adenosine were also detected in cat bladder ganglia with intracellular recording in in vitro ganglion preparations (3). The ganglionic excitatory effects of ATP were confirmed with patch clamp recording on 
cultured parasympathetic ganglion cells from neonatal rat major pelvic ganglia (45).

Immunohistochemical, molecular biological and pharmacological studies in the rat major pelvic ganglion revealed that the excitatory effects of ATP were mediated by $\mathrm{P} 2 \mathrm{X}_{2}$ receptors $(21,45)$. However, there are no reports of the distribution of the P2X and P2Y receptor protein in neurons in intramural ganglia of the cat bladder.

Two families of purinoceptors have been identified, a P2X ionotropic ligandgated ion channel family and a P2Y metabotropic G protein-coupled family $(2,34)$. Seven distinct $\mathrm{P} 2 \mathrm{X}$ subunits $\left(\mathrm{P} 2 \mathrm{X}_{1}\right.$ to $\left.\mathrm{P} 2 \mathrm{X}_{7}\right)$ have been cloned $(13,15)$ and shown to be expressed in primary sensory neurons $(21,41)$. So far eight mammalian P2Y receptors namely $\mathrm{P} 2 \mathrm{Y}_{1}, \mathrm{P} 2 \mathrm{Y}_{2}, \mathrm{P} 2 \mathrm{Y}_{4}, \mathrm{P}_{2} \mathrm{Y}_{6}, \mathrm{P} 2 \mathrm{Y}_{11}, \mathrm{P} 2 \mathrm{Y}_{12}(25,44), \mathrm{P} 2 \mathrm{Y}_{13}(16)$ and the more recent $\mathrm{P}_{2} \mathrm{Y}_{14}$ receptor (1) have been cloned and shown to be activated by extracellular nucleotides.

The present study was carried out to determine the expression patterns of $\mathrm{P} 2 \mathrm{X}$ and $\mathrm{P} 2 \mathrm{Y}$ receptor in the intramural ganglia of cat bladder. We also examined the colocalization of $\mathrm{P} 2 \mathrm{X}_{3}$ and $\mathrm{P} 2 \mathrm{Y}_{4}$ receptors with choline acetyltransferase (ChAT), nitric oxide synthase (NOS) and neurofilament 200 (NF200) in intramural bladder neurones.

\section{Materials and Methods}

All procedures were conducted in accordance with Institutional Animal Care and Use Committee policies at each institution (Ohio State University, University of Pittsburgh and Home Office (UK) regulations covering regulated procedures).

\section{Tissue Preparation}


Intramural ganglia were removed from the surface of the urinary bladder from deeply anaesthetized ( $\alpha$ chloralose $60-70 \mathrm{mg} / \mathrm{kg} ; 2 \%$ halothane) healthy aged-matched mongrel cats (of either sex; 3.5-6 kg, $\mathrm{n}=10$ ). Following removal of tissues the animals were sacrificed via overdose of anaesthetic. Anaesthesia was determined to be adequate for surgery by periodically testing for the absence of a withdrawal reflex to a strong pinch of a hind paw and absence of an eye blink reflex to tactile stimuli of the cornea. The ganglia was fixed in $4 \%$ paraformaldehyde in $0.1 \mathrm{M}$ phosphate buffer $(\mathrm{PB} ; \mathrm{pH} 7.2)$ at $4^{\circ} \mathrm{C}$ overnight, and then transferred to $20 \%$ sucrose in phosphate buffered saline (PBS) (overnight at $4^{\circ} \mathrm{C}$ ). Thereafter, the tissue blocks were rapidly frozen by immersion in isopentane at $-70^{\circ} \mathrm{C}$ for $2 \mathrm{~min}$. Transverse sections through the ganglia (10 $\mu \mathrm{m}$ thickness) were cut on a cryostat and thaw-mounted on poly-L-lysine-coated slides.

\section{Antisera}

The following primary antisera were used in the current studies: rabbit anti-P2 $\mathrm{Y}_{1}, \mathrm{P} 2 \mathrm{Y}_{2}$, $\mathrm{P}_{2} \mathrm{Y}_{4}, \mathrm{P}_{2} \mathrm{Y}_{6}$ and $\mathrm{P} 2 \mathrm{Y}_{12}$ receptors $(3 \mu \mathrm{g} / \mathrm{ml}$; Alomone Laboratories, Jerusalem, Israel). The immunogens used for production of polyclonal $\mathrm{P} 2 \mathrm{Y}_{1}, \mathrm{P}_{2} \mathrm{Y}_{2}, \mathrm{P} 2 \mathrm{Y}_{4}$ and $\mathrm{P} 2 \mathrm{Y}_{12}$ antibody were synthetic peptides corresponding to the carboxyl terminal of the cloned rat $\mathrm{P} 2 \mathrm{Y}_{1}$, $\mathrm{P}_{2} \mathrm{Y}_{2}, \mathrm{P}_{2} \mathrm{Y}_{4}$ and $\mathrm{P} 2 \mathrm{Y}_{12}$ receptors, covalently linked to keyhole limpet hemocyanin. The $\mathrm{P} 2 \mathrm{Y}_{6}$ receptor antibody is produced from the $\mathrm{C}$ terminus and the $\mathrm{P} 2 \mathrm{Y}_{12}$ receptor antibody from the second intracellular loop between TM3 and TM 4. The peptide sequences of the $\mathrm{P} 2 \mathrm{Y}_{1}, \mathrm{P} 2 \mathrm{Y}_{2}, \mathrm{P} 2 \mathrm{Y}_{4}, \mathrm{P} 2 \mathrm{Y}_{6}$ and $\mathrm{P} 2 \mathrm{Y}_{12}$ receptors are of amino acid sequence 242-258 (RALIYKDLDNSPLRRKS), 227-244 (KPAYGTTGLPRAKRKSVR), 337-350 (HEESISRWADTHQD), 311-328 (QPHDLLQKLTAKWQRQRV) and 125-142 
(KTTRPFKTSNPKNLLGAK) respectively. Rabbit anti-P2X $\mathrm{X}_{1}-\mathrm{P} 2 \mathrm{X}_{7}$ receptor antibodies $(2.5 \mu \mathrm{g} / \mathrm{ml})$ were provided by Roche Palo Alto (CA, USA). The other antisera used in this study as well as their respective dilutions, are listed in Table 1.

\section{Immunocytochemistry}

An indirect immunofluorescence method was used to visualize receptor expression. Briefly, the sections were washed $3 \times 5$ min in PBS, then preincubated with $0.2 \%$ Triton X-100 in PBS (0.1 M) for $30 \mathrm{~min}$. The sections were then incubated overnight with the primary antibodies $\left(\mathrm{P} 2 \mathrm{X}_{1}-\mathrm{P} 2 \mathrm{X}_{7}, \mathrm{P} 2 \mathrm{Y}_{1}, \mathrm{P} 2 \mathrm{Y}_{2}, \mathrm{P} 2 \mathrm{Y}_{6}\right.$ and $\left.\mathrm{P} 2 \mathrm{Y}_{12}\right)$ diluted to $3 \mu \mathrm{g} / \mathrm{ml}$ with $10 \%$ normal horse serum (NHS) in PBS containing $0.05 \%$ merthiolate and $0.2 \%$ Triton $\mathrm{X}-100$. Subsequently, the sections were incubated with Cy3-conjugated donkey antirabbit IgG, diluted 1:300 in 1\% NHS in PBS containing 0.05\% merthiolate for $1 \mathrm{~h}$. All incubations were held at room temperature and separated by three 5-min washes in PBS. Slides were mounted with Citifluor (Citifluor Ltd, London, UK) and examined with fluorescence microscopy. Control experiments were performed using an excess of the appropriate homologue peptide antigen to absorb the primary antibodies and thus confirm a specific immunoreaction.

Sections on which counts of $\mathrm{P} 2 \mathrm{X}$ and $\mathrm{P} 2 \mathrm{Y}$ receptor positive neurons had been performed were marked and then counterstained with toluidine blue $(2.5 \%$ in $0.1 \mathrm{M} \mathrm{PB}$ for 2 min followed by dehydration through increasing grades of alcohol, cleared in xylene, and cover slipped with DPX mounting medium). This enabled the total neurons numbers to be determined by counting all neurons in the marked sections under brightfield illumination. Immunoreactive-positive and -negative neurones were counted to 
calculate the proportion of positive neurones.

\section{Immunofluorescence double labeling}

To demonstrate the colocalization of the $\mathrm{P}_{2} \mathrm{X}_{3}$ and $\mathrm{P} 2 \mathrm{Y}_{4}$ receptor with ChAT, neuronal NOS, and medium molecular-weight neurofilament marker (NF200), sections were immunostained for the $\mathrm{P} 2 \mathrm{X}_{3}$ or $\mathrm{P} 2 \mathrm{Y}_{4}$ receptor, as above, then incubated with these antibody overnight. Subsequently the sections were incubated with FITC-conjugated donkey anti-goat IgG, or FITC-conjugated donkey anti-sheep IgG, or FITC-conjugated donkey anti-mouse IgG. All the incubations and reaction were held at room temperature and separated by 3x10 min washes in PBS. The sections were mounted with Citifluor and examined with fluorescence microscopy.

In colocalization studies investigating the coexpression of $\mathrm{P}_{2} \mathrm{Y}_{4}$ and $\mathrm{P} 2 \mathrm{X}_{3}$ receptors, $\mathrm{P}_{2} \mathrm{Y}_{4}$ receptor immunoreactivity was enhanced with tyramide amplification, which allows high sensitivity and low background specificity (Renaissance, TSA indirect, NEN, USA). The use of TSA allows immunostaining with two rabbit antisera, as described previously $(7,36)$. Briefly, sections were incubated in $10 \%$ NHS in PBS for 30 min at room temperature, followed by incubation with the $\mathrm{P}_{2} \mathrm{Y}_{4}$ antibody $(1 \mu \mathrm{g} / \mathrm{ml})$ in $10 \%$ NHS and $0.2 \%$ Triton X-100 in PBS, overnight. Subsequently the sections were incubated with biotinylated donkey anti-rabbit IgG for 1h, with Extravidin peroxidase for 1h, biotinylated tyramide for $8 \mathrm{~min}$, and then in Streptavidin-FITC for 10min. Polyclonal rabbit antibody against the $\mathrm{P} 2 \mathrm{X}_{3}$ receptor subtype was applied as a second primary antibody and detected with Cy3-conjugated donkey anti-rabbit IgG. To check for noncross-reactivity, $\mathrm{P}_{2} \mathrm{Y}_{4}$ receptor immunostaining using indirect TSA was performed alone 
on some sections, as was $\mathrm{P}_{2} \mathrm{X}_{3}$ receptor indirect immunofluorescence. The localization of each marker appeared identical to the localization observed with the double staining technique, with no apparent cross-reactivity.

For immunostaining a number of controls were performed on sections where either the primary or secondary antibody stage was omitted from the staining procedure.

\section{Cell Culture}

Cat intramural bladder ganglia were visualized under a dissecting microscope, carefully removed and transferred into ice-cold $\left(4^{\circ} \mathrm{C}\right)$ calcium/magnesium free Hanks balanced salt solution (HBSS; Invitrogen, Carlsbad, CA) of the following composition (in mM): $170 \mathrm{NaCl}, 7 \mathrm{KCl}, 1.6 \mathrm{Na}_{2} \mathrm{HPO}_{4}, 6 \mathrm{D}$-glucose and $0.01 \%$ phenol red, pH 7.3 (Invitrogen). Under a dissecting microscope, the intramural bladder ganglia were cut into smaller sections with sterile scissors, and transferred into pre-activated $\left(37^{\circ} \mathrm{C}\right.$ for $\left.10 \mathrm{~min}\right)$ membrane filter sterilized $\left(0.2 \mu \mathrm{m}^{2}\right)$, HBSS solution containing l-cysteine $\left(2 \mathrm{mg} \mathrm{ml}^{-1}\right)$ and papain $\left(14\right.$ units $\mathrm{ml}^{-1}$ ), for $15 \mathrm{~min}$ at $37^{\circ} \mathrm{C}$. The solution was carefully removed and replaced with membrane filter sterilized $\left(0.2 \mu \mathrm{m}^{2}\right)$ HBSS containing dispase $\left(8\right.$ units $\left.^{-1}\right)$ and Sigma blend A collagenase ( $1 \mathrm{mg} \mathrm{ml}^{-1}$; Sigma Chemical Co., Poole, UK) and incubated at $37^{\circ} \mathrm{C}$. Individual neurons were dissociated by gentle mechanical trituration with a sterile fire polished glass pipette, over a period of between 30-45 min, until tissue fragments were no longer visible macroscopically.

Dissociated intramural bladder ganglia neurons were centrifuged at $200 \mathrm{~g}$ for 15 min, the dispase/collagenase supernatant removed and pellet resuspended in neurobasal media supplemented with B27 (Invitrogen), salivary gland nerve growth factor (2.5S 
NGF, 10ng ml ${ }^{-1}$, Sigma) and $0.3 \%$ penicillin/streptomycin (Invitrogen) and fetal bovine serum $(10 \%)$. Following another wash in growth media, the cells were plated onto sterile rat-tail collagen coated $(0.01 \%) 31 \mathrm{~mm}$ glass coverslips, at a density of approximately $50 / \mathrm{cm}^{2}$ on 6 well sterile culture dish and maintained at $37^{\circ} \mathrm{C}$ in a humidified incubator $\left(95 \% \mathrm{O}_{2} / 5 \% \mathrm{CO}_{2}\right)$. Growth media was changed every 2 days.

\section{Calcium imaging of cultured cat bladder ganglion neurons}

Cultured cat intramural ganglia neurons (2-5days following plating) were incubated with the fluorescent $\mathrm{Ca}^{2+}$ indicator, fura-2-acetoxymethyl (AM) (5 $\mu \mathrm{M}$, Invitrogen) in HBSS containing bovine serum albumin $\left(5 \mathrm{mg} \mathrm{ml}^{-1}\right)$ for $30 \mathrm{~min}$ at $37^{\circ} \mathrm{C}$ in an atmosphere of 5 $\% \mathrm{CO}_{2}$. Cells were washed in $\mathrm{HBSS}$ (containing in $\mathrm{mM}$; $\mathrm{NaCl} 138, \mathrm{KCl} 5, \mathrm{KH}_{2} \mathrm{PO}_{4} 0.3$, $\mathrm{NaHCO}_{3} 4, \mathrm{CaCl}_{2} 2, \mathrm{MgCl}_{2}$ 1, HEPES 10, glucose 5.6, pH 7.35, 310 mosm l-1), transferred to a perfusion chamber and mounted onto an epifluorescence microscope (Olympus, IX70). Measurement of $\left[\mathrm{Ca}^{2+}\right]_{\mathrm{i}}$ was performed by ratiometric imaging of fura2-AM at 340 and $380 \mathrm{~nm}(100 \mathrm{~Hz})$ and the emitted light monitored at $510 \mathrm{~nm}$. The fluorescence ratio, F340/F380 was calculated and acquired by C-Imaging systems (Compix Inc, PA, USA) and background fluorescence subtracted. All test agents were bath applied (flow rate $=1.5 \mathrm{ml} \mathrm{min}^{-1}$ ). Data was obtained from a minimum of 5 independent cultures, unless stated otherwise.

\section{Photomicroscopy}

Images of immunofluorescence labeling were taken with the Leica DC 200 digital camera (Leica, Heerbrugg, Switzerland) attached to a Zeiss Axioplan microscope (Zeiss, 
Oberkochen, Germany). Images were imported into a graphics package (Adobe

Photoshop 5.0, USA). The two-channel readings for green and red fluorescence were merged by using Adobe-Photoshop 5.0.

\section{Analysis}

All analyses were performed bind using $\mathrm{x} 20$ objective magnification. P2X and P2Y receptor expression in ganglia was determined by counting all $\mathrm{P} 2 \mathrm{X}$ and $\mathrm{P} 2 \mathrm{Y}$ receptorpositive neurons in every sixth section throughout the ganglia from each animal. Scores for P2X and P2Y immunostaining were made by using a personal, subjective, graded scale varying from -, undetectable staining; +, weak staining but distinguishable from background, or scattered cells with moderate intensity staining; ++, moderate intensity staining in over $30 \%$ of cells; +++ , very intense immunoreactivity in over $30 \%$ of cells. This analysis is a purely personal evaluation based on extensive experience and not meant as a quantitative analysis.

To calculate percentages of $\mathrm{P} 2 \mathrm{X}_{3}$ and $\mathrm{P} 2 \mathrm{Y}_{4}$ receptor colocalization with cytochemical markers, 4 randomly selected ganglia sections were chosen for each pair of markers for each animal. For each section, counts were made of the number of positive neurons for $\mathrm{P}_{2} \mathrm{X}_{3}$ or $\mathrm{P}_{2} \mathrm{Y}_{4}$ receptor, the number of positive neurons for the other marker and the number of neurons expressing both antigens and percentages were calculated.

\section{Results}

$P 2 X$ and $P 2 Y$ receptor-staining in the intramural ganglia of the cat urinary bladder The polyclonal antibodies for the seven P2X and four P2Y receptor subtypes labelled 
neurons in the intramural ganglia of the cat urinary bladder with differing intensity (Table 2; Figs.1 and 2). In control experiments, no signal was observed when the pre-immune sera were used. Antibodies for all P2X receptor subtypes produced neuronal staining. $\mathrm{P} 2 \mathrm{X}_{3}$ receptor staining was the most intense and was detected in $95 \%$ of the neurons (Fig 1C). The staining was evenly distributed throughout the cytoplasm of these cells. The expression of $\mathrm{P} 2 \mathrm{X}_{1}, \mathrm{P} 2 \mathrm{X}_{2}$ and $\mathrm{P} 2 \mathrm{X}_{4}$ receptors (Fig $\left.1 \mathrm{~A}, \mathrm{~B}, \mathrm{D}\right)$ in the intramural ganglia was lower than that of $\mathrm{P} 2 \mathrm{X}_{3}$ receptors, but higher than that of $\mathrm{P} 2 \mathrm{X}_{5}, \mathrm{P} 2 \mathrm{X}_{6}$ or $\mathrm{P} 2 \mathrm{X}_{7}$ receptors (Fig 1E, F, G). The intensity of staining of the seven $\mathrm{P} 2 \mathrm{X}$ receptors in the intramural ganglia was in the order of $\mathrm{P} 2 \mathrm{X}_{3}>\mathrm{P} 2 \mathrm{X}_{1}=\mathrm{P} 2 \mathrm{X}_{2}=\mathrm{P} 2 \mathrm{X}_{4}>\mathrm{P} 2 \mathrm{X}_{5}=\mathrm{P} 2 \mathrm{X}_{6}=\mathrm{P} 2 \mathrm{X}_{7}$. Neurons in the intramural ganglia of the cat urinary bladder were shown to express $\mathrm{P} 2 \mathrm{Y}_{2}$, $\mathrm{P} 2 \mathrm{Y}_{4}, \mathrm{P}_{2} \mathrm{Y}_{6}$ and $\mathrm{P} 2 \mathrm{Y}_{12}$ receptor subtypes (Table 2; Fig 2), while $\mathrm{P} 2 \mathrm{Y}_{1}$ receptor antibodies labelled glial cells, but not neurons. $\mathrm{P} 2 \mathrm{Y}_{2}, \mathrm{P}_{2} \mathrm{Y}_{4}, \mathrm{P} 2 \mathrm{Y}_{6}$ and $\mathrm{P} 2 \mathrm{Y}_{12}$ receptor polyclonal antibodies labelled over $50 \%$ of the neurons with high intensity (Fig 2C,D,E,F). The staining was evenly distributed throughout the cytoplasm of these cells and positively labelled cells were randomly distributed throughout the ganglia. Figure 2A shows a control with no significant background staining after displacement with the relevant P2Y receptor peptide.

\section{Coexpression of $\mathrm{P} 2 \mathrm{X}_{3}$ receptors with ChAT, NOS and NF200}

Double-labeling or colocalization studies showed that all (100\%) of the $\mathrm{P} 2 \mathrm{X}_{3}$ receptor neurons in the intramural ganglia of the cat urinary bladder expressed ChAT immunoreactivity (Table 3, Fig. 3A-C). Only about $48.8 \%$ of the $\mathrm{P}_{2} \mathrm{X}_{3}$ receptor neurons expressed NOS immunoreactivity. However, $98.1 \%$ of NOS immunoreactive neurons 
also immunoreactive for $\mathrm{P}_{2} \mathrm{X}_{3}$ receptor (Table 3, Fig. 3D). A majority (97.4\%) of the $\mathrm{P} 2 \mathrm{X}_{3}$ receptor positive neurons exhibited NF200 immunoreactivity (Table 3. Fig. 3E).

Coexpression of $\mathrm{P}^{2} \mathrm{Y}_{4}$ receptors with ChAT, NOS and NF200

A double immunofluorescence method revealed all (100\%) of neurons positive for $\mathrm{P}_{2} \mathrm{Y}_{4}$ receptor colocalization with ChAT. On the other hand, only $37.5 \%$ of ChATimmunoreactive neurons exhibited $\mathrm{P}_{2} \mathrm{Y}_{4}$ receptor immunoreactivity (Table 3, Fig. 3F-H). $59.2 \%$ of $\mathrm{P}_{2} \mathrm{Y}_{4}$ receptor neurons expressed NOS immunoreactivity; whereas $45.7 \%$ of NOS immunoreactive neurons also immunoreactive for $\mathrm{P}_{2} \mathrm{Y}_{4}$ receptor (Table 3, Fig. 3I). Double immunofluorescence showed that $97.6 \%$ of $\mathrm{P}_{2} \mathrm{Y}_{4}$ receptor neurons were also NF200-immunoreactive. Conversely, 32.3\% of NF200-immunoreactive neurons coexpressed $\mathrm{P}_{2} \mathrm{Y}_{4}$ receptors (Table 3, Fig. 3J).

Co-localisation of $\mathrm{P} 2 \mathrm{X}_{3}$ with $\mathrm{P}_{2} \mathrm{Y}_{4}$ receptors

In the intramural ganglia of the cat urinary bladder, $\mathrm{P} 2 \mathrm{X}_{3}$ receptor immunoreactivity was very often co-expressed with $\mathrm{P}_{2} \mathrm{Y}_{4}$ receptor immunoreactivity. About $36.8 \%$ of $\mathrm{P} 2 \mathrm{X}_{3}$ receptor neurons were also found to be $\mathrm{P}_{2} \mathrm{Y}_{4}$ receptor immunoreactive. Conversely, $100 \%$ of $\mathrm{P}_{2} \mathrm{Y}_{4}$-immunoreactive neurons coexpressed $\mathrm{P} 2 \mathrm{X}_{3}$ receptor (Fig. $3 \mathrm{~K}$ ). In general, a greater number of neurons appeared to display $\mathrm{P} 2 \mathrm{X}_{3}$ rather than $\mathrm{P}_{2} \mathrm{Y}_{4}$ receptors (Fig. 1C, 2D).

Calcium imaging of cultured cat bladder intramural ganglion neurons Calcium imaging techniques were used to determine if purinergic agonists evoked 
functional responses in cultured cat intramural ganglia neurons. In this series of experiments, bath applied ATP $(10 \mu \mathrm{M})$ and uridine 5'-triphosphate (UTP; $10 \mu \mathrm{M})$ produced a rapid increase in $\left[\mathrm{Ca}^{2+}\right]_{\mathrm{i}}$ in cultured intramural neurons (Fig. 4A,C). The response typically reached a peak 1 minute post-ATP/UTP application and fully recovered to baseline within 2-3 minutes post agonist application. Approximately $58 \%$ and $62 \%$ tested responded with an elevation in $\left[\mathrm{Ca}^{2+}\right]_{\mathrm{i}}$ following application of UTP (10 $\mu \mathrm{M}, 163 / 108$ neurons; $\mathrm{n}=5$ independent cultures $)$ and ATP $(10 \mu \mathrm{M}, 13 / 21$ neurons; $\mathrm{n}=2$ independent cultures), respectively. Bath application of $\alpha, \beta$-methylene ATP $(\alpha, \beta$-meATP; Fig. 4B,D; $10 \mu \mathrm{M})$, a potent activator of $\mathrm{P} 2 \mathrm{X}_{1}$ and $\mathrm{P} 2 \mathrm{X}_{3}$ receptors also caused a rapid increase in a subpopulation of intramural neurons $(12.6 \%, 11 / 87$ neurons; $n=5$ independent cultures). It is possible that the low percentage of neurons responding to $\alpha, \beta$ meATP may have been due to rapid desensitization of the $\mathrm{P} 2 \mathrm{X}_{1}$ and $\mathrm{P} 2 \mathrm{X}_{3}$ receptors (27) or because the culture medium contained phenol red, which is known to antagonize $\mathrm{P} 2 \mathrm{X}_{1}$ and $\mathrm{P} 2 \mathrm{X}_{3}$ receptors (28). All the neurons that were responsive to $\alpha, \beta$-meATP $(10 \mu \mathrm{M})$ were also responsive to UTP. ATP $\gamma \mathrm{S}($ Fig $4 \mathrm{E} ; 10 \mu \mathrm{M})$, a particularly active agonist at $\mathrm{P} 2 \mathrm{X}_{5}$ receptors, evoked an increase in $\left[\mathrm{Ca}^{2+}\right]_{\mathrm{i}}$ in a subpopulation of intramural neurons, ( $50 \% ; 10 / 20$ neurons; $n=3$ independent cultures). Fig. 4F shows a representative cultured cat intramural neuron loaded with the calcium indicator, fura-2AM.

\section{Discussion}

In the present experiments immunohistochemical methods techniques revealed that neurons in the intact intramural parasympathetic ganglia of the cat urinary bladder express a variety of $\mathrm{P} 2 \mathrm{X}$ and $\mathrm{P} 2 \mathrm{Y}$ purinergic receptor subtypes. Purinergic agonists (ATP, 
UTP and $\alpha, \beta$-meATP) activated receptors in cultured dissociated ganglion cells eliciting an increase in intracellular $\mathrm{Ca}^{2+}$ concentration. A full receptor characterisation of the cultured ganglia was not carried out so that while it is assumed that receptor expression between the native and cultured neurons are the same, the presence of some differences cannot be ruled out. However, since the data obtained from this study are consistent with the results of earlier experiments $(3,18,40,45)$, the probability of native and cultured neurons having comparable receptor expression seems high. Our results indicate that purinergic agents can modulate synaptic transmission and alter the excitability of neurons in bladder and pelvic parasympathetic ganglia. The presence of multiple subtypes of purinergic receptors in bladder ganglia raises the possibility that purines may have complex synaptic modulatory functions in these ganglia.

We found that $95 \%$ and $40 \%$ of neurons in the intramural ganglia of the cat urinary bladder were $\mathrm{P} 2 \mathrm{X}_{3}$ and $\mathrm{P} 2 \mathrm{Y}_{4}$ receptor-immunoreactive respectively, and intensely stained. Approximately $37 \%$ of $\mathrm{P} 2 \mathrm{X}_{3}$ receptor-positive neurons co-expressed $\mathrm{P} 2 \mathrm{Y}_{4}$ receptors. Conversely, $100 \%$ of $\mathrm{P}_{2} \mathrm{Y}_{4}$ receptor-immunoreactive neurons co-expressed the $\mathrm{P} 2 \mathrm{X}_{3}$ receptors. This means that most $\mathrm{P} 2 \mathrm{X}_{3}$ and $\mathrm{P} 2 \mathrm{Y}_{4}$ receptors are located in the same neurons. Apart from $\mathrm{P} 2 \mathrm{X}_{3}$ and $\mathrm{P} 2 \mathrm{Y}_{4}$ receptors, immunoreactivity for $\mathrm{P} 2 \mathrm{X}_{1,2,4-7}$ and $\mathrm{P} 2 \mathrm{Y}_{2}, \mathrm{P}_{2} \mathrm{Y}_{6}$ and $\mathrm{P} 2 \mathrm{Y}_{12}$ receptor subtypes, was shown to be present on neurons in the intramural ganglia whereas $\mathrm{P} 2 \mathrm{Y}_{1}$ receptors were localized to glial cells in the ganglia.

In our previous study of cat $\mathrm{DRG}$, it was noted that $\mathrm{P}_{2} \mathrm{Y}_{1}$ receptor expression was very low on neurons but there was significant labelling of glial cells (35). Similarly, $\mathrm{P}_{2} \mathrm{Y}_{1}$ receptor expression and function has been reported on glial cells in a study of mouse SCG (12). There is widespread expression of P2Y receptors on glial cells and it has been 
suggested that they might have important roles in neuron-glial interactions (11).

The staining for $\mathrm{P} 2 \mathrm{X}_{3}$ and $\mathrm{P} 2 \mathrm{Y}_{4}$ receptors, the two of the most heavily expressed $\mathrm{P} 2$ receptor subtypes was also linked with the expression of other cytochemical markers, ChAT, NOS and NF200. ChAT is the enzyme responsible for the synthesis of ACh and anti-ChAT has been the specific antiserum of choice for the localization of ACh $(23,43)$. The present results show that all (100\%) of the neurons exhibiting $\mathrm{P} 2 \mathrm{X}_{3}$ and $\mathrm{P} 2 \mathrm{Y}_{4}$ receptor-immunoreactivity in the intramural ganglia of the cat urinary bladder expressed ChAT immunoreactivity. This indicates that $\mathrm{P} 2 \mathrm{X}_{3}$ and $\mathrm{P} 2 \mathrm{Y}_{4}$ receptors are localized on parasympathetic cholinergic postganglionic neurons in the bladder ganglia of the cat. $\mathrm{P} 2 \mathrm{X}_{3}$ receptors, previously thought to be selectively expressed in sensory neurones, have been shown recently to be localized also on neurons on some parasympathetic ganglia, notably rat otic, sphenopalatine and submandibular ganglia (31). The present study showing expression of $\mathrm{P} 2 \mathrm{X}_{3}$ receptors on parasympathetic neurons in cat intramural ganglia is consistent with these findings. In sensory neurons ATP elicits a depolarisation by eliciting fast- and slow-inactivating inward currents. The fast-inactivating ATP currents are mediated by homomeric $\mathrm{P}_{2} \mathrm{X}_{3}$ receptors, whereas the slow-desensitising currents are mediated by heteromeric $\mathrm{P} 2 \mathrm{X}_{2 / 3}$ receptors $(7,9)$. ATP also evokes responses in nociceptive sensory nerves through metabotropic P2Y receptors (24, 36, 39). The P2Y receptors couple through $\mathrm{G}$ proteins to various second messenger pathways mediating slower metabotropic responses. The increases in intracellular $\mathrm{Ca}^{2+}$ in bladder ganglion cells elicited by $\alpha, \beta$-meATP are likely mediated by P2X receptors; whereas the responses to UTP are attributable to activation of $\mathrm{P} 2 \mathrm{Y}$ receptors. The response to ATP could be mediated by activation of both types of receptors. In contrast to 
the prominent expression of $\mathrm{P} 2 \mathrm{X}_{3}$ receptors in cat bladder ganglia, $\mathrm{P} 2 \mathrm{X}_{2}$ receptors are highly expressed in the rat major pelvic ganglion and mediate the rapidly activating and slowly inactivating ATP-induced inward currents $(21,45)$.

The small percentage of neurons that responsed to $\alpha, \beta$-meATP might reflect that the receptor was desensitized, $\mathrm{P} 2 \mathrm{X}_{3}$ receptors are known to desensitize rapidly (27), however, the possibility that the cultured neurons expressed a different complement of $\mathrm{P} 2 \mathrm{X}$ receptor subtypes should also be considered, which might lead to variations in the sensitivity to $\alpha, \beta$-meATP.

NO has been identified as a neuronal messenger in the lower urinary tract (5). The enzyme responsible for the synthesis of NO from L-arginine, NOS, has been detected by using an antibody directed against NOS (8). NOS immunoreactivity has been detected in $45 \%$ of the intramural neurons of the guinea pig urinary bladder $(37,38,46,47)$. It has been suggested that NO maybe involved in the relaxation activity in the bladder base during micturition $(37,38,46,47)$. Our study has demonstrated the $48 \%$ and $59 \%$ of neurons expressing $\mathrm{P} 2 \mathrm{X}_{3}$ and $\mathrm{P} 2 \mathrm{Y}_{4}$ receptor-immunoreactivity, respectively, also exhibited NOS immunoreactivity. This subpopulation of parasympathetic neurons may have special functions in the bladder mediated by the co-release of ACh and NO.

NF200 is a marker of both A $\delta$-fibers sensory neurons, which play an important role in nociception and for the large-diameter neurons known to have myelinated axons and to be predominantly responsive to mechanical stimuli $(29,33)$. However, we found that most of the neurons in the intramural ganglia of the cat urinary bladder staining for $\mathrm{P}_{2} \mathrm{X}_{3}$ receptors and ChAT were NF200-positive (see Table 3). Double immunofluorescence showed that about $97 \%$ of $\mathrm{P}_{2} \mathrm{X}_{3}$ and $\mathrm{P} 2 \mathrm{Y}_{4}$ receptor immunoreactive 
neurons were NF200-immunoreactive. This is an unexpected finding because bladder parasympathetic postganglionic neurons are thought to have unmyelinated axons and therefore should not express a marker for neurons with myelinated axons. This antibody has been successfully used in a previous study (35), although the percentages of P2X and P2Y receptor subtypes that were NF200 immunoreactive were significantly less. The possibility that the observed high percentages of $\mathrm{P} 2 \mathrm{X}$ and $\mathrm{P} 2 \mathrm{Y}$ receptors that colocalised with NF200 was due to non-specific staining cannot be ignored.

The presence of purinergic receptors at sites of cholinergic transmission in bladder parasympathetic ganglia raises the question of the physiological significance of these receptors. The urinary bladder has two functions: to store and periodically release urine. These functions are regulated by complex nervous control originating in the central nervous system and passing through ganglionic synapses in the pelvic plexus and in the bladder wall $(20,30)$. The peripheral ganglia have integrative as well as relay functions and are involved in coordinating sympathetic and parasympathetic inputs to the bladder (19). In addition to classical transmitters NE and ACh, other putative neurotransmitters or neuromodulators, including VIP, SP, CGRP, enkephalin, somatostatin, neuropeptide Y, ATP and NO, have been identified in intramural ganglia and in nerves supplying the bladder and urethra of various species $(17,32,37,38,46,47)$ indicating that transmission in the efferent pathways to the bladder is complex.

Previous pharmacological studies revealed that ATP administered by intra-arterial injection to cat parasympathetic bladder ganglion cells in vivo can excite or inhibit synaptic transmission depending on the dose $(18,40)$ whereas adenosine, AMP and ADP have an inhibitory effect. The ganglionic inhibitory effects of ATP and adenosine are 
blocked by theophylline and therefore must be mediated by P1 receptors. Stimulation of preganglionic nerves in an in vitro cat bladder ganglion preparation produced a hyperpolarisation of the ganglion cells that was elicited by an adenosine-like substance acting on P1 purinergic receptors (3). It is not known whether adenosine is released directly by preganglionic nerves or produced by the metabolism of ATP released by nerve stimulation.

ATP might arise from several sources in the ganglia. It is known that axons of the parasympathetic ganglion cells release ATP as well as ACh at terminals in the bladder smooth muscle (10). Thus ATP might also be released from the soma and dendrites of parasympathetic ganglion cells and act in an auto-feedback manner on to the purinergic receptors on the same cells. In addition, because parasympathetic ganglia in the cat bladder receive inputs from various types of axons including: [1] parasympathetic preganglionic axons in the pelvic nerve arising in the sacral spinal cord, [2] lumbar sympathetic preganglionic and postganglionic axons in the hypogastric nerve, [3] sympathetic postganglionic axons from the caudal sympathetic chain ganglia travelling in the pelvic nerve and [4] afferent axons originating in the lumbosacral dorsal root ganglia and passing through the pelvic and hypogastric nerves to the bladder ganglia $(20,30)$, the purinergic receptors in the bladder ganglionic cells might be activated by transmitters released from multiple neural pathways.

Purinergic mechanisms in cat bladder ganglia could have a significant impact on the ganglionic function because synaptic transmission in these ganglia occurs with a low safety factor and is very sensitive to homosynaptic and heterosynaptic modulatory mechanisms that inhibit or facilitate transmission (19). Other ganglia such as the rat 
major pelvic ganglion where cholinergic synaptic transmission occurs with a high safety factor (19) might be less susceptible to purinergic modulation.

In conclusion the presence of various subtypes of purinergic receptors in the cat bladder ganglia as well as at other sites in the bladder including the smooth muscle (10), afferent nerves and urothelial cells lining the bladder lumen (6) indicates that purinergic mechanisms have the potential for exerting a broad influence on the neural regulation of micturition in the cat.

Acknowledgements: NIH DKR01 57284; grant from Roche Palo Alto (to LAB). 


\section{References}

1. Abbracchio MP, Boeynaems JM, Barnard EA, Boyer JL, Kennedy C, MirasPortugal MT, King BF, Gachet C, Jacobson KA, Weisman GA, and Burnstock G. Characterization of the UDP-glucose receptor (re-named here the $\mathrm{P}_{2} \mathrm{Y}_{14}$ receptor) adds diversity to the $\mathrm{P} 2 \mathrm{Y}$ receptor family. Trends in Pharmacol Sci 24: 52-55, 2003.

2. Abbracchio MP, and Burnstock G. Purinoceptors: are there families of P2X and P2Y purinoceptors? Pharmacol Therap 64: 445-475, 1994.

3. Akasu T, Shinnick-Gallagher P, and Gallagher JP. Adenosine mediates a slow hyperpolarizing synaptic potential in autonomic neurones. Nature 311: 62-65, 1984.

4. Alm P, and Elmer M. Adrenergic and cholinergic innervation of the rat urinary bladder. Acta Physiol Scand 9: 36-45. 1975.

5. Bennett BC, Kruse MN, Roppolo JR, Flood HD, Fraser M, and de Groat WC. Neural control of urethral outlet activity in vivo: Role of nitric oxide. J Urol 153: 2004-2009, 1995.

6. Birder LA, Ruan HZ, Chopra B, Buffington CA, Roppolo JR, Ford ADPW, de Groat WC, and Burnstock G. Alterations in P2X and P2Y purinergic receptor expression in urinary bladder from normal cats and cats with interstitial cystitis. Am J Physiol 287: F1084-F1091, 2004.

7. Bradbury EJ, Burnstock G, and McMahon SB. The expression of $\mathrm{P} 2 \mathrm{X}_{3}$ purinoreceptors in sensory neurons: effects of axotomy and glial-derived neurotrophic factor. Mol Cell Neurosci 12: 256-268, 1998. 
8. Bredt DS, and Snyder SH. Isolation of nitric oxide synthase, a calmodulinrequiring enzyme. Proc Natl Acad Sci USA 87: 682-685, 1992.

9. Burgard EC, Niforatos W, van Biesen T, Lynch KJ, Touma E, Metzger RE, Kowaluk EA, and Jarvis MF. P2X receptor-mediated ionic currents in dorsal root ganglion neurons. J Neurophysiol 82: 1590 -1598, 1999.

10. Burnstock G. Purinergic signalling in lower urinary tract. In: Handbook of Experimental Pharmacology, Volume 151/I. Purinergic and Pyrimidinergic Signalling I - Molecular, Nervous and Urinogenitary System Function 151/I, edited by Abbracchio MP, Williams M. Berlin: Springer-Verlag, 2001, p. 423-515.

11. Burnstock G, and Knight GE. Cellular distribution and functions of P2 receptor subtypes in different systems. Int Rev Cytol 240: 31-304, 2004.

12. Calvert JA, tterbury-Thomas AE, Leon C, Forsythe ID, Gachet C, and Evans RJ. Evidence for P2Y1, P2Y2, P2Y6 and atypical UTP-sensitive receptors coupled to rises in intracellular calcium in mouse cultured superior cervical ganglion neurons and glia. Br J Pharmacol 143: 525-532, 2004.

13. Chen CC, Akopian AN, Sivilotti L, Colquhoun D, Burnstock G, and Wood JN. A P2X purinoceptor expressed by a subset of sensory neurons. Nature 377: 428-431, 1995.

14. Cockayne DA, Hamilton SG, Zhu AM, Dunn PM, Zhong Y, Novakovic S, Malmberg AM, Cain G, Berson A, Kassotakis L, Hedley L, Lachnit WG, Burnstock G, McMahon SB, and Ford AP. Urinary bladder hyporeflexia and reduced pain-related behaviour in $\mathrm{P}_{2} \mathrm{X}_{3}$-deficient mice. Nature 407: 951-952, 2000. 


\section{Collo G, North RA, Kawashima E, Merlo-Pich E, Neidhart S, Surprenant A,} and Buell G. Cloning of $\mathrm{P} 2 \mathrm{X}_{5}$ and $\mathrm{P} 2 \mathrm{X}_{6}$ receptors and the distribution and properties of an extended family of ATP-gated ion channels. J Neurosci 16: 24952507, 1996.

16. Communi D, Gonzalez NS, Detheux M, Brezillon S, Lannoy V, Parmentier M, and Boeynaems JM. Identification of a novel human ADP receptor coupled to Gi. J Biol Chem 44: 41479-41485, 2001.

17. Crowe R, Haven AJ, and Burnstock G. Intramural neurons of the guinea-pig urinary bladder: Histochemical localization of putative neurotransmitters in cultures and newborn animals. J Auton Nerv Syst 15: 319-339, 1986.

18. de Groat WC, and Booth AM. Inhibition and facilitation in parasympathetic ganglia. Fed Proc 39: 2990-2996, 1980.

19. de Groat WC, and Booth AM. Synaptic transmission in pelvic ganglia. In: Nervous Control of the Urogenital System: The Autonomic Nervous System, edited by Maggi CA. Switzerland: Harwood Academic Publishers, 1993, p. 291-347.

20. de Groat WC, Booth AM, and Yoshimura N. Neurophysiology of micturition and its modification in animal models of human disease. In: The Autonomic Nervous System, Vol. 3, Chapter 8, Nervous Control of the Urogenital System, edited by Maggi CA. London: Harwood Academic Publishers, 1993, p. 227-289.

21. Dunn PM, Zhong Y, AND Burnstock G. P2X receptors in peripheral neurons. Prog Neurobiol 65: 107-34, 2001.

22. Ferguson DR, Kennedy I, AND Burton TJ. ATP is released from rabbit urinary bladder epithelial cells by hydrostatic pressure changes-a possible sensory 
mechanism? J Physiol (Lond) 505: 503-511, 1997.

23. Furness JB, Costa M, AND Keast JR. Choline acetyltransferase and peptide immunoreactivity of submucous neurons in the small intestine of the guinea-pig. Cell Tissue Res 237: 329-336, 1984.

24. Gerevich Z, Borvendeg SJ, Schroder W, Franke H, Wirkner K, Nörenberg W, Furst S, Gillen C, and Illes P. Inhibition of N-type voltage-activated calcium channels in rat dorsal root ganglion neurons by $\mathrm{P} 2 \mathrm{Y}$ receptors is a possible mechanism of ADP-induced analgesia. J Neurosci 24: 797-807, 2004.

\section{Hollopeter G, Jantzen HM, Vincent D, Li G, England L, Ramakrishnan V,} Yang RB, Nurden A, Julius D, and Conley PB. Identification of the platelet ADP receptor targeted by antithrombotic drugs. Nature 409: 202-207, 2001.

26. James S, and Burnstock G. Localization of muscarinic receptors on somatostatin-like immunoreactive neurons of the newborn guinea pig urinary bladder in culture. Neurosci Lett 106: 13-18, 1989.

27. Kasakov L, and Burnstock G. The use of the slowly degradable analog, $\alpha, \beta$ methylene ATP, to produce desensitisation of the $\mathrm{P}_{2}$-purinoceptor: effect on nonadrenergic, non-cholinergic responses of the guinea-pig urinary bladder. Eur $J$ Pharmacol 86: 291-294, 1983.

\section{King BF, Liu M, Townsend-Nicholson A, Pfister J, Padilla F, Ford APDW,} and Burnstock G. Antagonism of ATP responses at P2X receptor subtypes by the pH indicator dye, Phenol Red. Brit J Pharmacol 145: 313-322. 2005.

29. Lawson SN, and Waddell PJ. Soma neurofilament immunoreactivity is related to cell size and fibre conduction velocity in rat primary sensory neurons. J Physiol 
(Lond) 435: 41-63, 1991.

30. Lincoln J, and Burnstock G. Autonomic innervation of the urinary bladder and urethra. In: Nervous Control of the Urogenital System: The Autonomic Nervous System, edited by Maggi CA. London: Harwood Academic Publishers, 2003, p.33-68.

31. Ma B, Ruan H-Z, Burnstock G, and Dunn PM. Differential expression of P2X receptors on neurons from different parasympathetic ganglia. Neuropharmacology 48: 766-777, 2005.

\section{Morrison J, Steers WD, Brading A, Blok B, Fry C, de Groat WC, Kakizaki} H, Levin R, and Thor K. Neurophysiology and neuropharmacology. In: Incontinence, edited by Abrams P, Cardozo L, Khoury S, Wein A. Jersey: Health Publications, Ltd., 2002, p. 83-164.

33. Perry MJ, Lawson SN, and Robertson J. Neurofilament immunoreactivity in populations of rat primary afferent neurons: a quantitative study of phosphorylated and non-phosphorylated subunits. J Neurocytol 20: 746-758, 1991.

34. Ralevic V, and Burnstock G. Receptors for purines and pyrimidines. Pharmacol Rev 50: 413-492, 1998.

\section{Ruan H-Z, Birder LA, de Groat WC, Tai C, Roppolo J, Buffington A, and} Burnstock G. Localization of P2X and P2Y receptors in dorsal root ganglia of the cat. J Histochem Cytochem 53: 1273-1282, 2005.

36. Ruan HZ, and Burnstock G. Localisation of $\mathrm{P}_{2} \mathrm{Y}_{1}$ and $\mathrm{P}_{2} \mathrm{Y}_{4}$ receptors in dorsal root, nodose and trigeminal ganglia of the rat. Histochem Cell Biol 120: 415-426, 
2003.

37. Saffrey MJ, Hassall CJS, Moules EW, and Burnstock G. NADPH-diaphorase and nitric oxide synthase are expressed by the majority of intramural neurons in the neonatal guinea pig urinary bladder. J Anat 185: 487-495, 1994.

38. Smet PJ, Jonavicius J, Marshall V, and de Vente J. Distribution of nitric oxide synthase -immunoreactive nerve and identification of the cellular targets of nitric oxide in guinea-pig and human urinary bladder by cGMP immunoreactivity. Neuroscience 71: 337-348, 1996.

39. Stucky CL, Medler KA, and Molliver DC. The P2Y agonist UTP activates cutaneous afferent fibers. Pain 109: 36-44, 2004.

40. Theobald RJ, and de Groat WC. The effects of purine nucleotides on transmission in vesical parasympathetic ganglia of the cat. J Auton Pharmacol 9: 167-182, 1989.

41. Ueno S, Yamada H, Moriyama T, Honda K, Takano Y, Kamiya H, and Katsuragi T. Measurement of dorsal root ganglion P2X mRNA by SYBR Green fluorescence. Brain Res Protocols 10: 95-101, 2002.

42. Vlaskovska M, Kasakov L, Rong W, Bodin P, Bardini M, Cockayne DA, Ford APDW, and Burnstock G. P2 $\mathrm{X}_{3}$ knockout mice reveal a major sensory role for urothelially released ATP. J Neurosci 21: 5670-5677, 2001.

43. Wang XY, Wong WC, and Ling EA. Localization of choline acetyltransferase and NADPH-diaphorase activities in the submucous ganglia of the guinea-pig colon. Brain Res 712: 107-116, 1996.

44. Zhang FL, Luo L, Gustafson E, Lachowicz J, Smith M, Qiao X, Liu YH, 
Chen G., Pramanik B, Laz TM, Palmer K, Bayne M, and Monsma FJ. ADP is the cognate ligand for the orphan G protein-coupled receptor SP1999. J Biol Chem 276: 8608-8615, 2001.

45. Zhong Y, Dunn PM, Xiang Z, Bo X, and Burnstock G. Pharmacological and molecular characterization of $\mathrm{P} 2 \mathrm{X}$ receptors in rat pelvic ganglion neurons. $\mathrm{Br} \mathrm{J}$ Pharmacol 125: 771-781, 1998.

46. Zhou Y, and Ling EA. Colocalization of nitric oxide synthase and some neurotransmitters in the intramural ganglia of the guinea pig urinary bladder. $J$ Comp Neurol 394: 496-505, 1998.

47. Zhou Y, Tan CK, and Ling EA. Distribution of NADPH-d and nitric oxide synthase-containing neurons in the intramural ganglia of guinea pig urinary bladder. J Anat 190: 135-145, 1997. 
Table 1. List of antisera used for immunocytochemistry

\begin{tabular}{|c|c|c|c|}
\hline Antigen & Host & Dilution & Source \\
\hline \multicolumn{4}{|l|}{ Primary antisera } \\
\hline $\mathrm{P} 2 \mathrm{X}_{1-7}$ receptors & Rabbit & $1: 400$ & $\begin{array}{l}\text { Roche Bioscience Palo Alto, CA, } \\
\text { USA }\end{array}$ \\
\hline $\begin{array}{l}\mathrm{P} 2 \mathrm{Y}_{1}, \mathrm{P} 2 \mathrm{Y}_{2}, \mathrm{P} 2 \mathrm{Y}_{4}, \mathrm{P} 2 \mathrm{Y}_{6} \\
\mathrm{P} 2 \mathrm{Y}_{12} \text { receptors }\end{array}$ & Rabbit & $1: 200$ & Alomone Labs, Jerusalem, Israel \\
\hline Choline acetyltransferase & Goat & $1: 100$ & $\begin{array}{l}\text { Chemicon international, Inc., } \\
\text { Temecula, CA, USA }\end{array}$ \\
\hline $\begin{array}{l}\text { Neuronal nitric oxide } \\
\text { synthase }\end{array}$ & Sheep & $1: 800$ & $\begin{array}{l}\text { Santa Cruz Biotechnology, Santa } \\
\text { Cruz, CA, USA }\end{array}$ \\
\hline $\begin{array}{l}\text { Medium molecular weight } \\
\text { neurofilament }\end{array}$ & Mouse & $1: 400$ & clone N52, Sigma, USA \\
\hline \multicolumn{4}{|l|}{$\begin{array}{l}\text { Secondary antisera and } \\
\text { streptavidin complexes }\end{array}$} \\
\hline $\begin{array}{l}\text { Cy3-conjugated donkey } \\
\text { anti-rabbit IgG }\end{array}$ & & $1: 300$ & $\begin{array}{l}\text { Jackson ImmunoResearch Lab, } \\
\text { West Grove, PA, USA }\end{array}$ \\
\hline $\begin{array}{l}\text { FITC-conjugated donkey } \\
\text { anti-goat IgG }\end{array}$ & & $1: 200$ & $\begin{array}{l}\text { Jackson ImmunoResearch Lab, } \\
\text { West Grove, PA, USA }\end{array}$ \\
\hline $\begin{array}{l}\text { FITC-conjugated donkey } \\
\text { anti-sheep IgG }\end{array}$ & & $1: 200$ & $\begin{array}{l}\text { Jackson ImmunoResearch Lab, } \\
\text { West Grove, PA, USA }\end{array}$ \\
\hline $\begin{array}{l}\text { FITC-conjugated donkey } \\
\text { anti-mouse IgG }\end{array}$ & & $1: 200$ & $\begin{array}{l}\text { Jackson ImmunoResearch Lab, } \\
\text { West Grove, PA, USA }\end{array}$ \\
\hline $\begin{array}{l}\text { Biotinylated donkey anti- } \\
\text { rabbit IgG }\end{array}$ & & $1: 500$ & $\begin{array}{l}\text { Jackson ImmunoResearch Lab, } \\
\text { West Grove, PA, USA }\end{array}$ \\
\hline Extravidin peroxidase & & $1: 1500$ & Sigma, USA \\
\hline Biotinylated tyramide & & $1: 50$ & $\begin{array}{l}\text { Renaissance, TSA indirect, NEN, } \\
\text { USA }\end{array}$ \\
\hline $\begin{array}{l}\text { Streptavidin-Fluorescein } \\
\text { (FITC-green fluorophore,) }\end{array}$ & & $1: 200$ & Amersham Biosciences, UK \\
\hline
\end{tabular}


Table 2. Comparison of intensity of immunoreactivities for $\mathrm{P} 2 \mathrm{X}_{1-7}$ and $\mathrm{P} 2 \mathrm{Y}_{1,2,4,6,12}$ receptors on neurons in intramural ganglia of the cat urinary bladder.

\begin{tabular}{|c|c|c|c|c|c|c|c|c|c|c|c|}
\hline $\mathrm{P}_{1} \mathrm{X}_{1}$ & $\mathrm{P}_{2} \mathrm{X}_{2}$ & $\mathrm{P}_{2} \mathrm{X}_{3}$ & $\mathrm{P}_{4} \mathrm{X}_{4}$ & $\mathrm{P}_{2} \mathrm{X}_{5}$ & $\mathrm{P}_{2 \mathrm{X}_{6}}$ & $\mathrm{P}_{2 \mathrm{X}_{7}}$ & $\mathrm{P}_{2} \mathrm{Y}_{1}$ & $\mathrm{P}_{2} \mathrm{Y}_{2}$ & $\mathrm{P}_{2} \mathrm{Y}_{4}$ & $\mathrm{P}_{2} \mathrm{Y}_{6}$ & $\mathrm{P}_{2} \mathrm{Y}_{12}$ \\
\hline++ & ++ & +++ & ++ & + & + & + & - & +++ & +++ & +++ & +++ \\
\hline
\end{tabular}

+++, strong signal; ++, moderate signal; +, weak signal; -, undetectable. 
Table 3. Colocalization of $\mathrm{P}_{2} \mathrm{X}_{3}$, or $\mathrm{P}_{2} \mathrm{Y}_{4}$ receptor immunoreactivity with ChAT, or NOS, or NF200 in intramural ganglia of the cat urinary bladder.

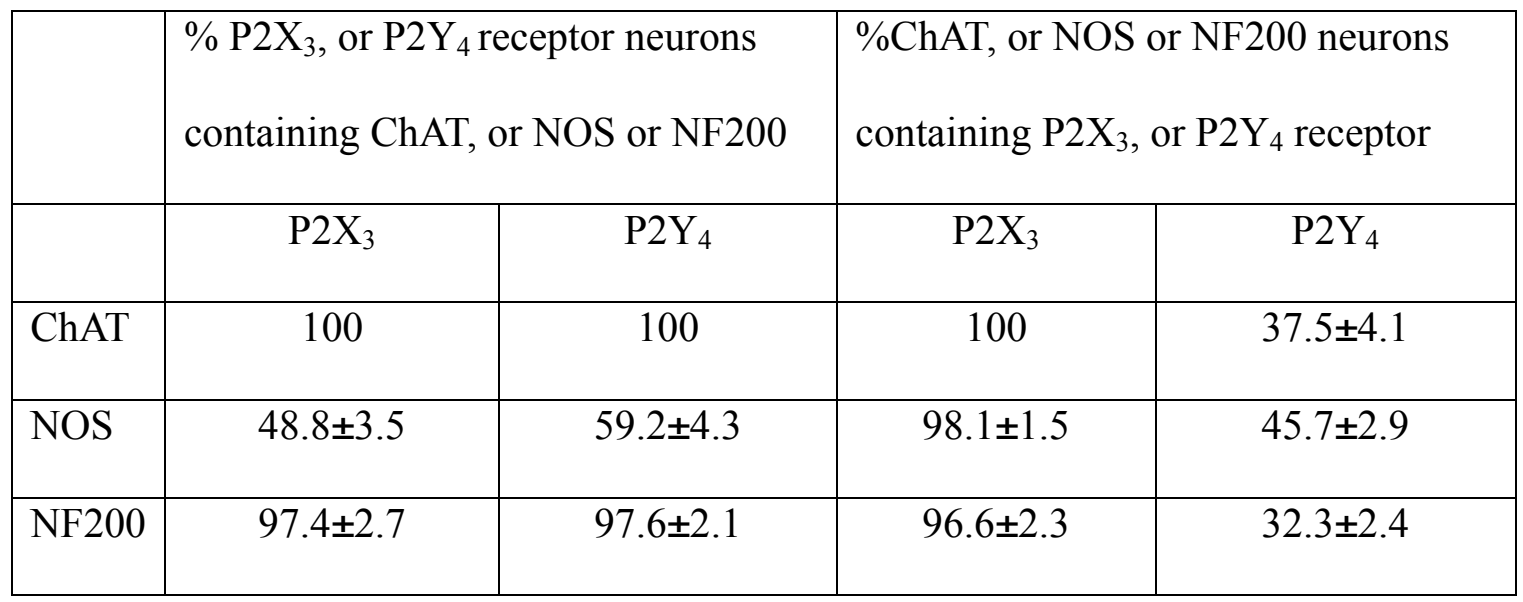

ChAT - choline acetyltransferase, NOS - neuronal nitric oxide synthase, NF200 - medium molecular weight neurofilament. 


\section{Figure Legends}

\section{Figure 1.}

Localization of P2X receptor subtype immunoreactivity in the intramural ganglia of the cat urinary bladder. A. $\mathrm{P} 2 \mathrm{X}_{1}$ receptor; B. $\mathrm{P} 2 \mathrm{X}_{2}$ receptor; C. $\mathrm{P} 2 \mathrm{X}_{3}$ receptor; D. $\mathrm{P} 2 \mathrm{X}_{4}$ receptor; E. P2 $\mathrm{X}_{5}$ receptor; F. P2X $\mathrm{X}_{6}$ receptor; G. P2X $\mathrm{X}_{7}$ receptor. Scale bar, $50 \mu \mathrm{m}$. 


\section{Figure 2.}

Localization of $\mathrm{P} 2 \mathrm{Y}$ receptor subtype immunoreactivity in the intramural ganglia of the cat urinary bladder. A. Control; B. P2Y 1 receptor; C. P2Y ${ }_{2}$ receptor; D. $\mathrm{P}_{2} \mathrm{Y}_{4}$ receptor; E. $\mathrm{P}_{2} \mathrm{Y}_{6}$ receptor; F. $\mathrm{P} 2 \mathrm{Y}_{12}$ receptor. Scale bar, $50 \mu \mathrm{m}$. 


\section{Figure 3.}

Double staining to show colocalization (yellow/orange) of $\mathrm{P}_{2} \mathrm{X}_{3}$ or $\mathrm{P}_{2} \mathrm{Y}_{4}$ receptor immunoreactivity (red) with ChAT, or NOS, or NF200 (green) in intramural ganglia of the cat urinary bladder. A-C: Double staining for P2X $\mathrm{X}_{3}$-IR and ChAT-IR. D. Double staining for $\mathrm{P}_{2} \mathrm{X}_{3}$-IR and NOS-IR. E. Double staining for P2 $\mathrm{X}_{3}$-IR and NF200-IR. F-H. Double staining for $\mathrm{P}_{2} \mathrm{Y}_{4}$-IR and ChAT-IR. I. Double staining for P2Y 4 -IR and NOS-IR. J. Double staining for $\mathrm{P}_{2} \mathrm{Y}_{4}$-IR and NF200-IR. K. Double staining for P2X 3 -IR (red) and $\mathrm{P}^{2} \mathrm{Y}_{4}$-IR (green). Scale bar, $50 \mu \mathrm{m}$. 


\section{Figure 4.}

Cultured cat intramural ganglia neurons express functional $\mathrm{P} 2 \mathrm{X}$ and $\mathrm{P} 2 \mathrm{Y}$ responses. A. Illustrates representative changes in $\left[\mathrm{Ca}^{2+}\right]_{\mathrm{i}}$ in cultured intramural cat ganglia neurons following bath-application of ATP $(10 \mu \mathrm{M})$ and UTP $(10 \mu \mathrm{M})$. B. $\alpha, \beta$-meATP $(10 \mu \mathrm{M})$ an activator of the ligand-gated ion channel, $\mathrm{P} 2 \mathrm{X}_{3}$, evoked an increase in $\left[\mathrm{Ca}^{2+}\right]_{\mathrm{i}}$ in a subpopulation of cat intramural neurons. C. UTP $(10 \mu \mathrm{M})$ an activator of the metabotropic purinergic receptors, $\mathrm{P} 2 \mathrm{Y}$, also evoked an increase in $\left[\mathrm{Ca}^{2+}\right]_{\mathrm{i}}$ in a subpopulation of cultured intramural neurons. D. All cultured cat intramural ganglia neurons that responded to $\alpha, \beta$-meATP $(10 \mu \mathrm{M})$ also responded to UTP $(10 \mu \mathrm{M})$. E. ATP $\gamma \mathrm{S}(10 \mu \mathrm{M})$ also evoked elevation of $\left[\mathrm{Ca}^{2+}\right]_{\mathrm{i}}$, demonstrating the presence of $\mathrm{P} 2 \mathrm{Y}_{2 / 4}$ receptors within intramural ganglia neurons F. Illustrates a representative cultured cat intramural neuron loaded with the calcium indicator, fura-2AM. 
Figure 1

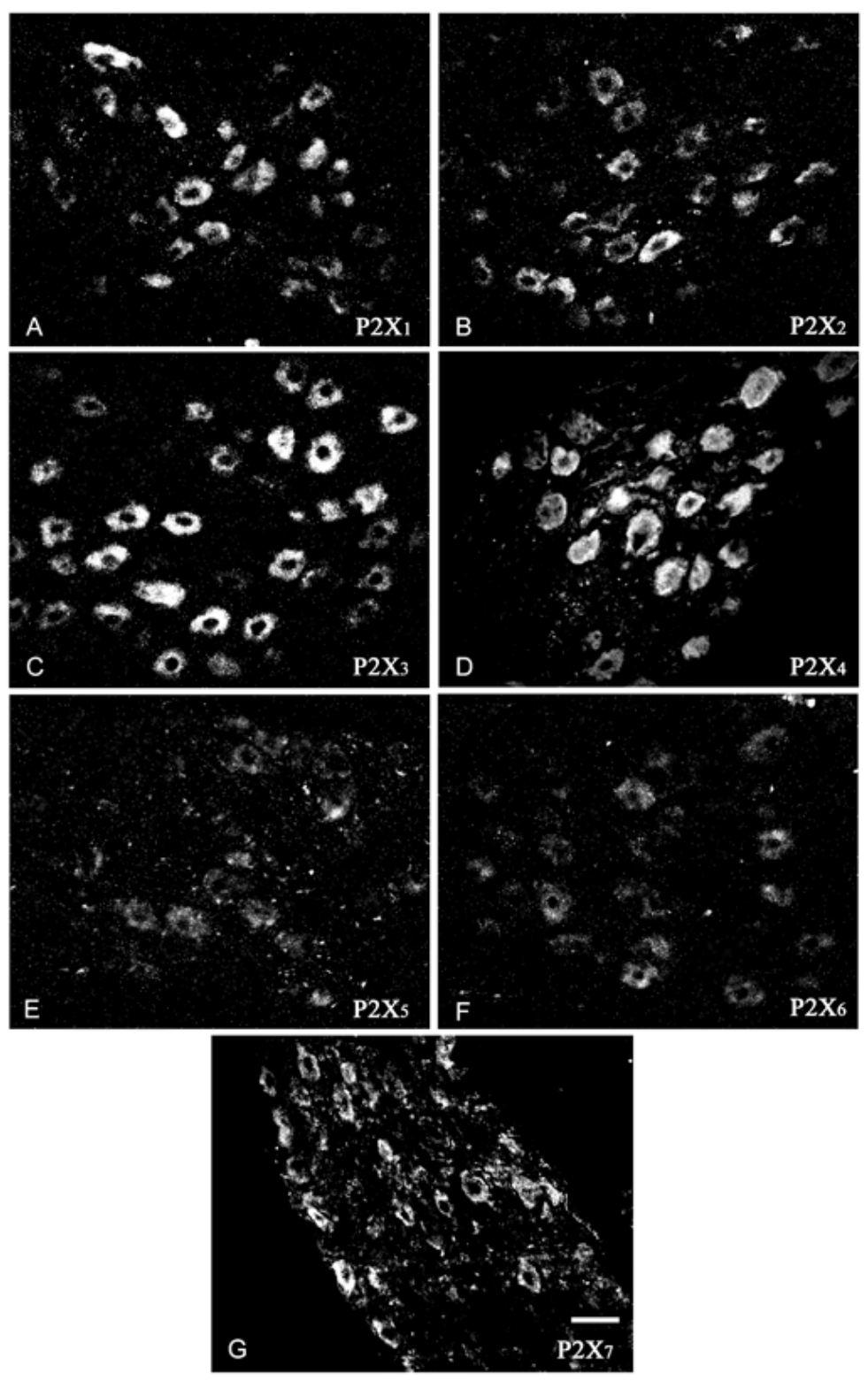


Figure 2
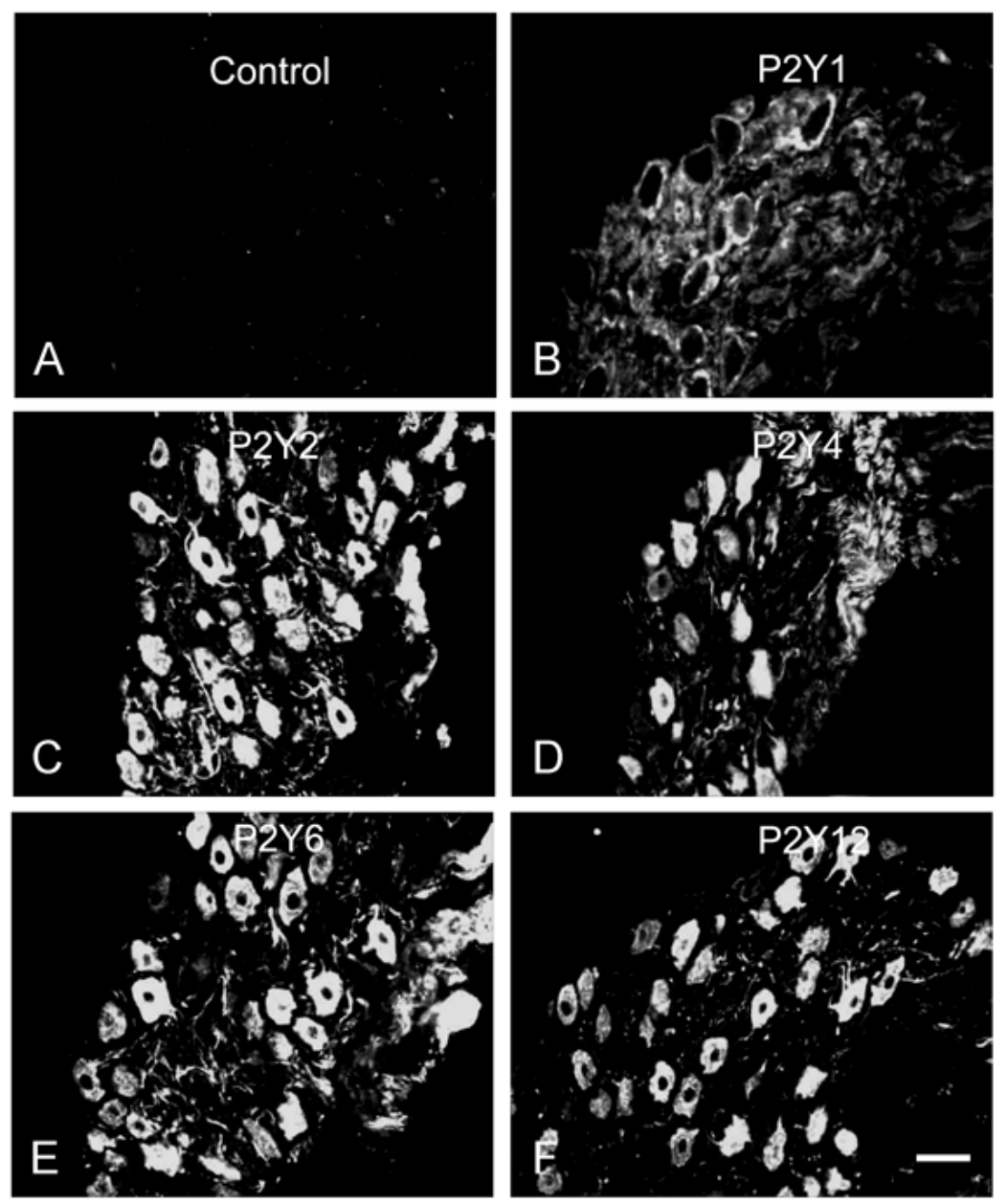
$\mathrm{P} 2$ receptor expression of cat bladder intramural ganglia

Figure 3
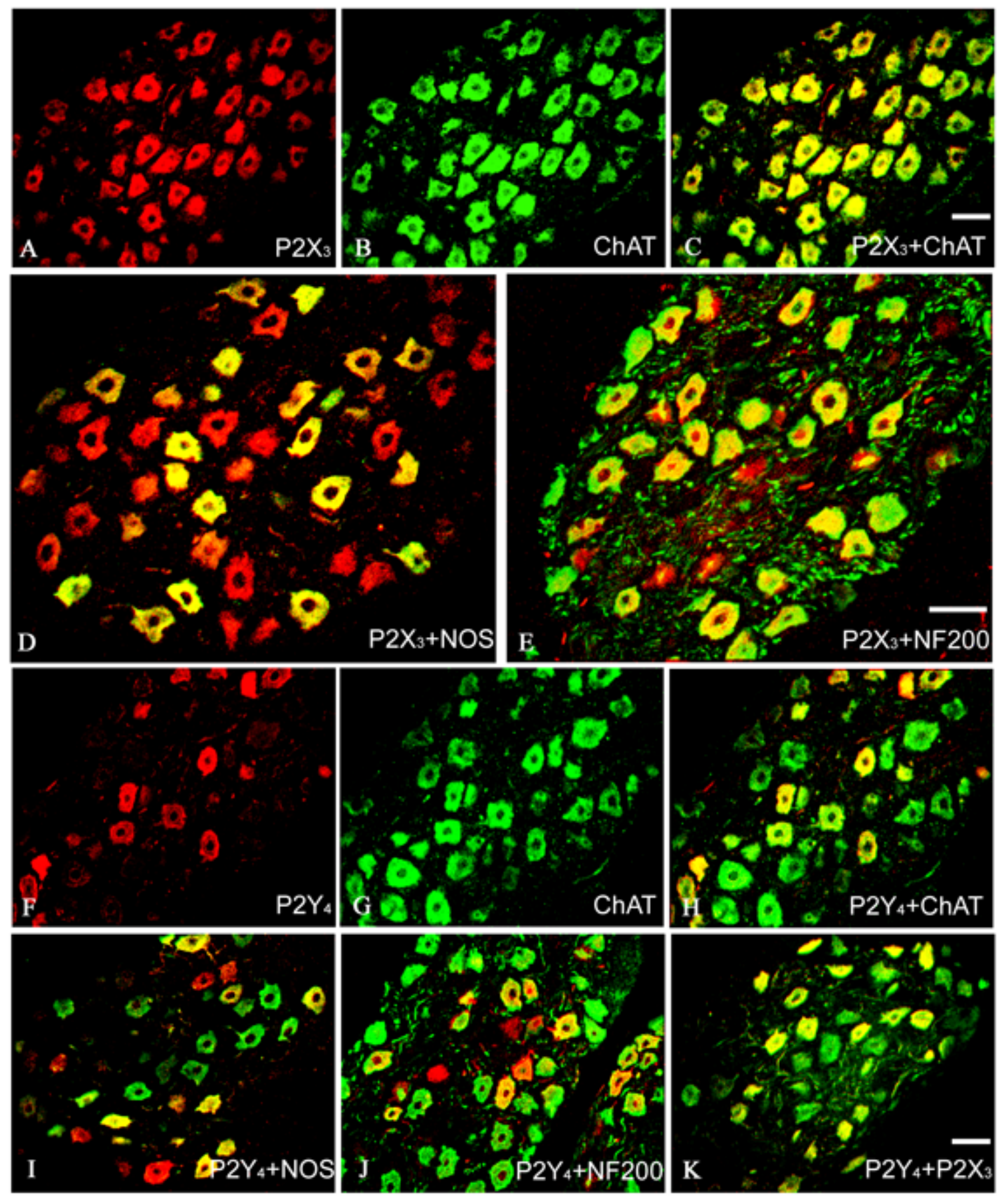
Figure 4
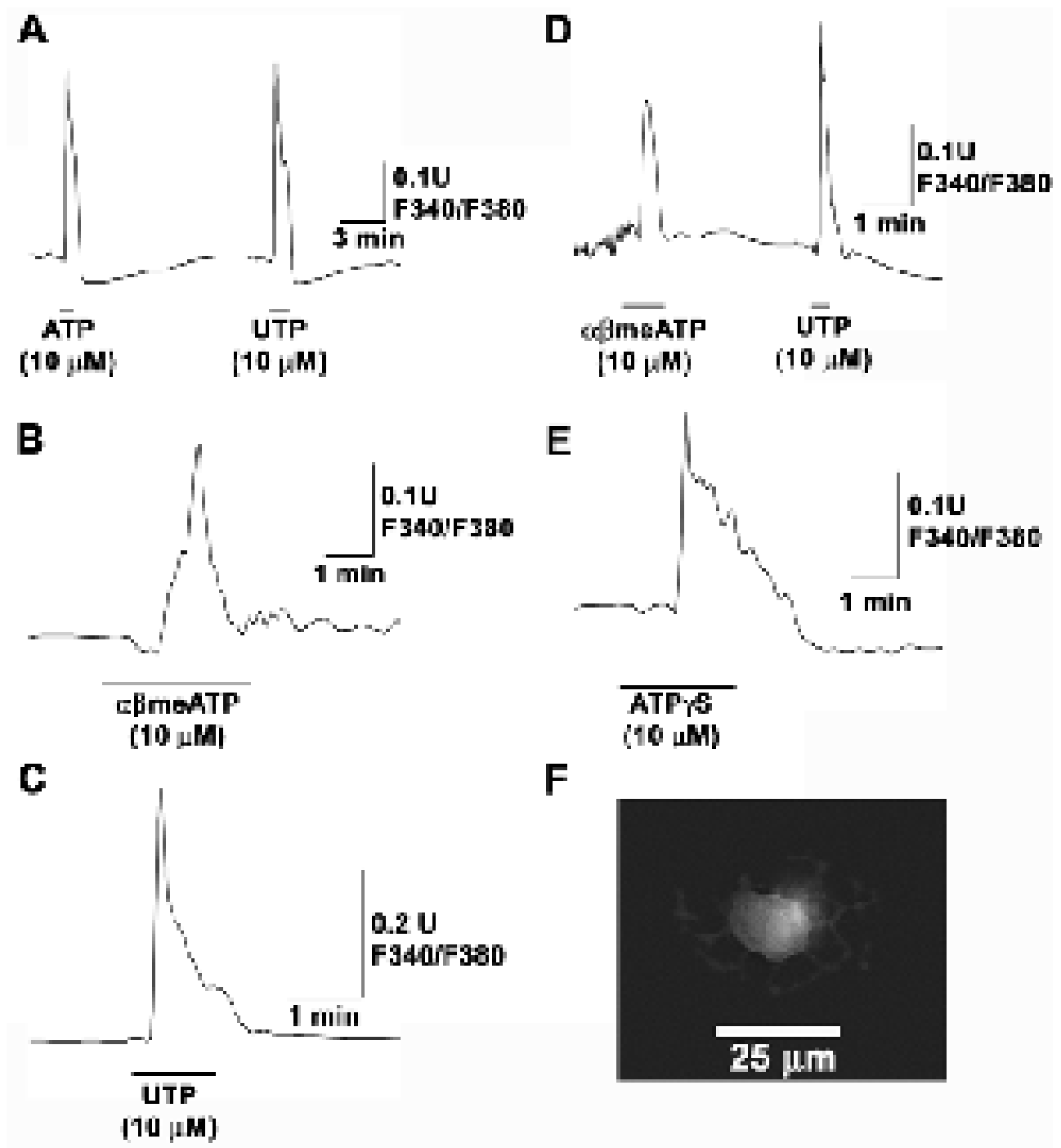

(10 य)

F

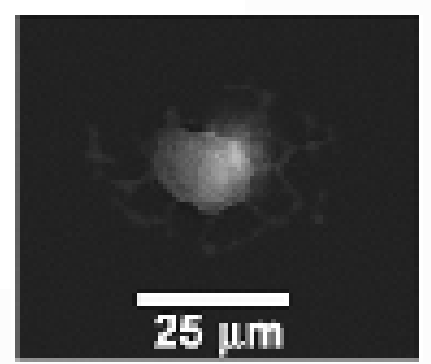

